\title{
Automotive Competence in Vocational High Schools and The Needs World of Industry
}

\author{
Siti Ulgari ${ }^{1}$, Herminarto Sofiyan ${ }^{2}$, Dwiki Muda Yulanto ${ }^{3}$, Henry Iskandar $^{3}$ \\ Universitas Negeri Medan, Indonesia ${ }^{1,3,4}$ \\ Yogyakarta State University, Indonesia ${ }^{2}$, \\ siti_ulgari@unimed.ac.id
}

\begin{abstract}
The purpose of the research was to know: (1) the mapping of vehicle engineering competency in vocational high school with competency that needed in the world of work/world of industry, (2) the level of automotive competency relevancies with work competency work needs in the world of work/world of industry. This research was quantitative descriptive research with survey method. Data collection technique that used was questionnaire. Data analysis technique in the study was quantitative descriptive statistics. The result of this study indicate that: (1) the mapping competence showed that the competency in the vocational high school's curriculum documents but was not the work competence that needed into the world of the industry including 67 items of competence with its percentage was $94 \%$; (2) the rate of relevance showed that there were 4 rounds of competence that did not relevant; 3 items of competence were in category relevant enough; 50 rounds were the competence that in the relevant categories and 14 competencies were highly relevant category.
\end{abstract}

Keywords: work competency needs, world of work/world of industry, relevance.

\section{Introduction}

Vocational high school can't be apart from the context of the present life and the anticipation of dynamic future context that growing systematically accordance with the globalization. Education in Indonesia is experiencing changes in the era of globalization today, which gives two adjoining impacts i.e. opportunities and challenges [1]. The readiness of a country to make a problem will become opportunities. Rather, unpreparedness of a country will make the chance of turning into a problem. The enactment of the Public Policies of the ASEAN economy (MEA) will bring the impact of intense competition not only in the market of goods and services but also the labor market to earn a chance at the job. If it is not ready with the condition that Indonesia will lose and become a user of products and foreign labor that is more competitive.

Maclean \& Wilson [2] said that "Technical and vocational education training (TVET) is concerned with the acquisition of knowledge and skills for the world of work". Within the framework of preparing and improving competitive advantage, then human resources into a "major 
force" for the industry in generating national excellence in the context of a more comprehensive and innovative.

One of the most decisive sectors in preparing human resources (HR) to have a competitive edge is the most strategic sectors as education in national development, with education expected in addition to being able to provide provision of knowledge, skills and attitudes can also have developed a wide range of skills needed by every Member of the community. TVET is concerned with the acquisition of knowledge and skills for the world of work. Vocational training as important as the other point; it is no longer enough to think that prisoners will acquire "good work habits' if they spend the day in unskilled factory work, because times have moved on [3].

One of the strategic steps that can be done to create the quality of human resources is through formal education. Formal education is education that structured and tiered. It consists of primary education, secondary education, and higher education. The secondary level of education was the Vocational High School. Vocational learning is what happens for vocational purposes at the local level". The field of vocational education is subject to sets of long-standing sentiments and precepts that have arisen through history and are reinforced by societal mores and practices that pervade both societal and professional discourses [4].

The purpose of the vocational education is very diverse. There are four purposes of vocational education based on the projects i.e. vocational education that focuses on (1) preparation for working life including informing individuals about their choice of an occupational; (2) the initial preparation of the individual to work life including developing the capacity for practice the work that has been selected; (3) the development was from individuals during their work according to the requirements of the performances of the transformation work time by time; and (4) the provisions of educational experience that supports the transition from one job to another job because a individuals choice or are forced to change jobs throughout their working lives [4].

Competence is very basic for vocational high school graduates to enter the workforce. Competencies acquired through learning activities in vocational high school from good theory or practice. Vocational education does not separate between theory and practice but integrates the skills practice with the relevant lessons that are the basis of knowledge for these skills. "Competency is the climax of rule guided learning and discovering how to cope in crowded, pressured contexts, where the proficiency marks the onset of quite a different approach to the job" [5]. Competency is a combination of skills, abilities, and knowledge needed to perform a specific task that is in its simplest meaning, "competency" means to be capable of doing something, often denoting a mastery or exceptional talent or skill" [6].

This concerns to the development of vocational high school that have been done through program development expertise that is relevant to the needs of the labor market. This program became the cutting edge of creating link and match with the world of work. The curriculum is a field of enquiry and action on all that bears on schooling, including content, teaching, learning and resources. The curriculum is concerned with what is planned, implemented, taught, learned, evaluated and researched in schools at all levels of education [7].

However, the success education will create graduates were absorbed by the field of business and employment, namely the issue of the suitability of the competence of graduates of each competency expertise with the needs of the world of work. Happening at this moment, the existence of the vocational high school is not fully based on analysis of labor requirements (demand and supply analysis). The facts on the ground that happens are supply driven. 
The solution of the problems that presented above is to conduct a study on the suitability of the curriculum that implemented in vocational high school with competencies that are needed in the workforce. The study was conducted to find out the competencies that taught in vocational high school but is not needed in the world of work and know the competencies are not taught in vocational high school however needed in the workforce. Ideally, the competencies taught in Vocational High School are also used in the world of work. The existence of the ideal conditions is then expected to occur the suitability between the educational world and the industrial world. Based on the description above, researcher interested to do a study about the "Automotive Competence in Vocational High Schools and The Needs of World of Industry".

\section{Research Method}

This research used descriptive quantitative research designs with the survey as an approach method. The purpose of this study to describe the data quantitatively and then dig up the facts and described in quantitative (numbers) based on the data of the population represented by sample about Light Vehicle Engineering competence of Vocational High School with the competence required by the business world or the world of industry.

Survey method that used to collect data from a particular natural place (unnatural), but researcher do the treatment in the data collection for example, by passing a questionnaire, structured interviews, tests, and so on [8]. This is in accordance with the statement of previous study that said that "... survey research involves the collection of information from a sample of individuals through their responses to questions" that is survey research is research that using collection of information from samples based on the response from the given questions.

The research's subject was the competence of Engineering Vehicle Lightweight, Automotive Engineering Program with work competency needed by the business world or the world of industry. Data source are taken from the head of the workshop, the head of the mechanics, the mechanics of world of work/world of industry automotive, Vehicle Engineering Program Teachers, and students of engineering Vehicle Lightweight competencies.

Data collection techniques used were interview documentation of observations. The technique of data analysis in this study used descriptive statistics data analysis techniques. The presentation of the data is done by data processing instrument competency curriculum of engineering Vehicle Lightweight of Vocational High School and competence required in the automotive industry in Medan. In the presentation of the descriptive statistical data will be presented the measures of descriptive statistics, namely the size of the Byway, Sum, Mean, Median, and Mode of each item instrument.

The presentation of data use SPSS software (Statistical product and service Solution) version 23 for Windows and Microsoft Excel software 2016. SPSS version 23 is used to manipulate and present data about the determination of the classification of the category is irrelevant, Less relevant, quite relevant, relevant, and highly relevant, and presents data in the form of a table of distribution the frequency and percentage. Microsoft Excel software used 2016 presenting data in the form of graphs and manipulate data research instrument, henceforth becoming the data ready to be processed using the Software SPSS version 23. 


\section{Results and Discussion}

The description of research's result about the analysis of Light Vehicle Engineering, automotive program competence in Vocational High School and its relevance with the world of industry's competence in the engineering of light vehicle field are presented in descriptive statistic measurement, distribution of frequency table, and the percentage graph of each competence item that examined on quantitative data.

\section{1) The Structure of The Light Vehicle Engineering Competence}

Vehicle Engineering program curriculum was a lightweight in vocational high school refers to the regulation of the minister of education and culture of the Republic of Indonesia number 60 in the year 2013 of the curriculum of vocational high school 2013, where there were 70 competences. Based on the results of the data processing here was the structure of the charge light vehicle engineering competency program skills of automotive.

Table 1. The Structure of The Charge Light Vehicle Engineering Competence

\begin{tabular}{lll}
\hline No. & \multicolumn{1}{c}{ Subject } & \multicolumn{1}{c}{ Competency } \\
\hline Maintenance & Maintain the main engine system and valve mechanism \\
Periodically & Maintain periodic lubrication system \\
& Periodically maintain the cooling system \\
& Periodically maintain the gasoline fuel system \\
& conventional / carburetor \\
& Periodically maintain the gasoline fuel injection system (Electronic \\
& Fuel Injection / EFI) \\
& Periodically maintain the Engine Management System (EMS) \\
& Periodically maintain the In-Line injection pump diesel fuel \\
& system \\
& Periodically maintain the rotary injection pump diesel fuel system \\
& Periodically maintain the Common Rail diesel fuel system \\
& Perform periodic maintenance checks of vehicle engines \\
& Improve the cylinder head mechanism and accessories \\
& Improve cylinder block mechanism and \\
& The completeness \\
& Improve the Lubrication system \\
& Improve the Cooling system \\
& Improve the gasoline fuel system \\
& conventional / carburetor \\
& Improve the fuel injection gasoline system (Electronic Fuel \\
& Injection / EFI) \\
& Improve Engine Management System (EMS) \\
& Improved the In-Line injection pump diesel fuel system \\
& Repairing the Rotary injection pump diesel fuel system \\
& Improved the Common Rail diesel fuel system \\
& Reporting the results of improvements to light vehicle engines \\
\hline Chassis Maintenance & Maintain periodic clutches \\
and & Maintain periodic Manual transmissions \\
\hline &
\end{tabular}




\begin{tabular}{|c|c|c|}
\hline No. & Subject & Competency \\
\hline & $\begin{array}{l}\text { Transfer } \\
\text { Light }\end{array}$ & $\begin{array}{l}\text { Maintain periodic Automatic transmission } \\
\text { Periodically maintain the Propeller shaft } \\
\text { Maintain periodic Differential } \\
\text { Periodically maintain the axle } \\
\text { Periodically maintain the conventional brake system } \\
\text { Periodically maintain the Antilock Break System (ABS) } \\
\text { Periodically maintain the Suspense system } \\
\text { Periodically maintain the steering system and Power Steering } \\
\text { Carry out Removing, Installing and Adjusting the Wheel } \\
\text { Carry out Dismantling, Repairing and Installing Inner and Inner } \\
\text { Tires } \\
\text { Carry Out Choosing Tires and Rims For Special Use } \\
\text { Conduct final testing of the results of regular maintenance of the } \\
\text { chassis and the transfer of power } \\
\text { Fix the clutch } \\
\text { Repair Manual transmission } \\
\text { Repair Automatic transmission } \\
\text { Repair the propeller shaft } \\
\text { Fix Differential } \\
\text { Repairing the axle } \\
\text { Repairing Conventional brake systems } \\
\text { Repairing Antilock Break System (ABS) } \\
\text { Repair the suspense system } \\
\text { Improve the steering system } \\
\text { Improve Spooring } \\
\text { Fix Wheel / Tire Balans } \\
\text { Repairing the rim } \\
\text { Conduct final testing of the results of the chassis repair and } \\
\text { transfer of power }\end{array}$ \\
\hline 3 & $\begin{array}{l}\text { Maintenance of } \\
\text { Electric Vehicle Light }\end{array}$ & $\begin{array}{l}\text { Maintain periodic electrical system } \\
\text { Installing Additional Electrical Equipment (Accessories) } \\
\text { Periodically maintain the starter system } \\
\text { Periodically maintain the charging system } \\
\text { Maintain regular ignition systems } \\
\text { Conventional } \\
\text { Maintain regular electronic ignition systems } \\
\text { Periodically maintain the lighting system and instrument panel } \\
\text { Maintain periodic Air Conditioning (AC) systems } \\
\text { Periodically maintain the audio system } \\
\text { Periodically maintain the safety system } \\
\text { Perform the results of periodic maintenance of electrical light } \\
\text { vehicles } \\
\text { Improve the electricity system and additional equipment } \\
\text { Improve system start } \\
\text { Improve the charging system } \\
\text { Improve conventional ignition systems } \\
\text { Improve electronic ignition systems }\end{array}$ \\
\hline
\end{tabular}




\begin{tabular}{ll}
\hline No. & Subject \\
\hline & Improve lighting and panel systems \\
& Instrument \\
& Improve the Air conditioning (AC) system \\
& Improve audio system \\
& Improving the safety system \\
& Manage the results of electrical improvements in light vehicles \\
\hline
\end{tabular}

\section{2) Map Light Vehicle Engineering Competency Program Automotive Expertise SMK Negeri needed by business/industry}

The identification of competencies into the needs of the business world/industrial Vehicle engineering package Lightly had done in 10 (ten) main dealers of Vehicle Engineering Light in Medan city. Identification of competences had done by either using the enclosed questionnaire technique with the number of 40 respondents from 10 (ten) main dealers.

The description of the results of the study showed that there were 70 items of competency package engineering Vehicle Lightweight Vocational High School. It consists of 21 items of engine maintenance light vehicle competence, 28 items competence maintenance chassis and a lightweight vehicle power mover, and 21 rounds of competence maintenance electrical light vehicles.

The number of 70 competencies needs of the world of work became a business/industrial world needs identified regarding levels - (the important). The level of urgency of every item of competence was obtained from the sum of the value (score) is obtained at any granule competence, the higher the amount of value (score) is obtained when the higher the degree of urgency of the item also competence. Vice versa, the lower the number value (score) that is obtained at the low level of urgency of the item also competence. Presented the following level of urgency of every grain of competency package engineering Vehicle Lightweight Vocational High School.

\section{a. Vehicle Engine Maintenance Light}

The engine maintenance light vehicle consists of 21 competence, based on the results of research to the competence of the maintenance of the competence of all light vehicle mean became competency work needed business/industry. In the field of competence maintenance, light vehicle engines are the lowest level of urgency is the grain of the competence to understand the fuel system with a total value of 125 being and percentage of $62.5 \%$. The level of urgency of the highest was the grain of the competence to understand how to take care of the machine at regular intervals (periodic service with a total of 163 value and percentage of $8.15 \%$ ).

Explained that the subject vehicle lighter machine maintenance all competencies are in the category of less relevant with the percentage of $9.5 \%$, the category was quite relevant to $14.3 \%$, the percentage of relevant categories with percentages $52.4 \%$, the category was very relevant to the percentage of $24.8 \%$. Based on images can be outlined that required the presence of relevance between Vocational High School curriculum with competency work contained in the world of work and the industry to increase levels of graduate absorbed Vocational High School. 


\section{b. Maintenance of the Chassis and a lightweight Vehicle Power Mover}

Maintenance of the chassis and the transfer of power light vehicles consist of 28 competencies, based on the results of research for competence maintenance chassis light vehicle power mover and all basic competencies into the competency of the work required by the world of business/industry. In the field of competence maintenance chassis light vehicle power mover and this is the lowest level of urgency is the grain of competence keep driving wheel with 138 total value and percentage of $69 \%$. The level of urgency of the highest is the grain of the competence to understand the transmission with a total value of 176 and percentage $88 \%$.

Explained that the subjects of the chassis and vehicle power mover lightweight competence are in the category of categories is quite relevant to $10.7 \%$, the percentage of categories relevant to the percentage of $71.4 \%$, the category is very relevant with the percentage of $17.9 \%$. Based on figure 02 can be outlined that it needs the presence of relevance between vocational high school curriculum with competency work in the business world or the world of the industry to increase levels of graduate absorbed vocational high school.

\section{c. Electrical Light Vehicle Maintenance}

Maintenance of electrical light vehicles consists of 21 basic competences, based on the results of research for electrical light vehicle maintenance competence all basic competence be competency work needed by the business world/world industry. In the field of electrical light vehicle maintenance, competence is the lowest level of urgency is the grain of the competence to understand the system of radio with 132 total value and percentage of $66 \%$. The level of urgency of the highest is keeping the competence of grain/service system fuel injection petrol engines with a total value of 178 and percentage of $89 \%$.

The percentage of each category on the subjects of electricity light vehicle maintenance can be outlined as in Figure 03 below. Explained that the subjects light vehicle electrical competencies were in the category of categories was quite relevant to the percentage of $9.5 \%$, the category was relevant to the percentage of $71.4 \%$, the category was very relevant with the percentage $19.1 \%$. Based on figure 3 passable that it needs the presence of relevance between Vocational High School curriculum with competency work in the business world or the world of the industry to increase levels of graduate absorbed Vocational High School.

The competency percentage entered in the category of less relevant $2 / 71 \times 100 \%=2.82 \%$, the percentage of competence quite relevant $8 / 71 \times 100 \%=11.27 \%$, the percentage of relevant competence is $52 / 71 \times 100 \%=73.23$, percentage and highly relevant competence is $9 / 71 \times 100 \%=$ $12.68 \%$.

\section{The level of relevance of competencies between the competencies of engineering Vehicle Light Vocational High School with competency that needed by the business world or the world of industry.}

The analysis on the level of relevance of competencies needed to work in the business world or the world industry had done in 10 (ten) main Vehicle Lightweight Engineering dealers. Analysis on the level of competence of relevance had done using the technique of calculate the percentage values (\% score) was obtained by each grain of competence, the higher the percentage values $(\%$ score) was obtained when the higher levels also the relevance of the competencies of the grains. So 
is a good idea, the lower the percentage values (\% score) obtained when the lower level also the relevance of the competencies of the grains. Here were presented the level of relevance of each grain of Light Vehicle Engineering competencies, namely:

a. Vehicle Engine Maintenance Light

The engine maintenance light vehicle consists of 21 competencies. In a review of the level of competence of relevance to engine maintenance light vehicle that all competencies included in categories relevant to the order level of relevance as the following table:

Table 2. Relevance Rating of Competence Vehicle Engine Maintenance Light

\begin{tabular}{cccccc}
\hline No. & Competence & $\begin{array}{c}\text { Relevance Rating } \\
(\mathbf{\%})\end{array}$ & No. & Competence & $\begin{array}{c}\text { Relevance Rating } \\
(\mathbf{\%})\end{array}$ \\
\hline $\mathbf{1}$ & PM1 & $95.32 \%$ & 12 & PM12 & $89.24 \%$ \\
$\mathbf{2}$ & PM2 & $95.58 \%$ & 13 & PM13 & $90.57 \%$ \\
$\mathbf{3}$ & PM3 & $91.69 \%$ & 14 & PM14 & $88.99 \%$ \\
$\mathbf{4}$ & PM4 & $93.25 \%$ & 15 & PM15 & $92.32 \%$ \\
$\mathbf{5}$ & PM5 & $92.73 \%$ & 16 & PM16 & $95.23 \%$ \\
$\mathbf{6}$ & PM6 & $87.68 \%$ & 17 & PM17 & $89.93 \%$ \\
$\mathbf{7}$ & PM7 & $93.54 \%$ & 18 & PM18 & $92.14 \%$ \\
$\mathbf{8}$ & PM8 & $88.94 \%$ & 19 & PM19 & $89.77 \%$ \\
$\mathbf{9}$ & PM9 & $92.44 \%$ & 20 & PM20 & $89.59 \%$ \\
$\mathbf{1 0}$ & PM10 & $93.24 \%$ & 21 & PM21 & $88.99 \%$ \\
$\mathbf{1 1}$ & PM11 & $91.56 \%$ & & & \\
\hline
\end{tabular}

Based on explanation above this level of relevance, then it can be concluded that the degree of relevance on a vehicle's engine light maintenance of competence between the vehicle's engineering curriculum documents Lightweight Vocational High School with competency work needed by the world business or industry is $21 / 21 \times 100 \%=100 \%$, fall into the category of high relevance level.

\section{b. Maintenance of the Chassis and a lightweight Vehicle Power Mover}

Maintenance of the chassis and the power light vehicle mover consists of 26 competences, based on the results of data analysis all the competencies required by the business world or the world of industry. In a review of the level of relevance of the 28 competencies maintenance chassis and a lightweight vehicle power mover that was as the following table:

Table 3. Relevance Rating of competence maintenance chassis and a lightweight vehicle power

\begin{tabular}{cccccc}
\hline No. & Competence & $\begin{array}{c}\text { Relevance Rating } \\
(\mathbf{\%})\end{array}$ & No. & Competence & $\begin{array}{c}\text { Relevance Rating } \\
(\%)\end{array}$ \\
\hline $\mathbf{1}$ & PSPT1 & $91.25 \%$ & 15 & PSPT15 & $88.24 \%$ \\
$\mathbf{2}$ & PSPT2 & $88.99 \%$ & 16 & PSPT16 & $91.23 \%$ \\
$\mathbf{3}$ & PSPT3 & $90.54 \%$ & 17 & PSPT17 & $92.42 \%$ \\
$\mathbf{4}$ & PSPT4 & $91.36 \%$ & 18 & PSPT18 & $91.67 \%$ \\
$\mathbf{5}$ & PSPT5 & $89.44 \%$ & 19 & PSPT19 & $89.86 \%$ \\
$\mathbf{6}$ & PSPT6 & $92.42 \%$ & 20 & PSPT20 & $88.74 \%$ \\
$\mathbf{7}$ & PSPT7 & $91.33 \%$ & 21 & PSPT21 & $89.73 \%$ \\
$\mathbf{8}$ & PSPT8 & $89.99 \%$ & 22 & PSPT22 & $92.52 \%$ \\
\hline
\end{tabular}




\begin{tabular}{cccccc}
\hline No. & Competence & $\begin{array}{c}\text { Relevance Rating } \\
(\mathbf{\%})\end{array}$ & No. & Competence & $\begin{array}{c}\text { Relevance Rating } \\
(\%)\end{array}$ \\
\hline $\mathbf{9}$ & PSPT9 & $92.42 \%$ & 23 & PSPT23 & $92.22 \%$ \\
$\mathbf{1 0}$ & PSPT10 & $91.32 \%$ & 24 & PSPT24 & $91.42 \%$ \\
$\mathbf{1 1}$ & PSPT11 & $89.88 \%$ & 25 & PSPT25 & $88.55 \%$ \\
$\mathbf{1 2}$ & PSPT12 & $89.24 \%$ & 26 & PSPT26 & $87.98 \%$ \\
$\mathbf{1 3}$ & PSPT13 & $89.25 \%$ & 27 & PSPT27 & $98.42 \%$ \\
$\mathbf{1 4}$ & PSPT14 & $92.21 \%$ & 28 & PSPT28 & $91.33 \%$ \\
\hline
\end{tabular}

Based on explanation above this level of relevance, then it can be concluded that the degree of relevance on a vehicle's engine light maintenance of competence between the vehicle's engineering curriculum documents Lightweight in vocational high school with work competency needed by the business world or the world industry is $28 / 28 \times 100 \%=100 \%$, enter in the categories the level of relevance is high.

\section{c. Electrical Light Vehicle Maintenance}

Maintenance of electrical light vehicle consists of 21 competences. In a review of the level of competence of relevance to engine maintenance light vehicle that all competencies included in categories relevant to the order level of relevance as the following table:

Table 4. Relevance Rating of Competence Electrical Light Vehicle Maintenance

\begin{tabular}{cccccc}
\hline No. & Competence & $\begin{array}{c}\text { Relevance Rating } \\
(\mathbf{\%})\end{array}$ & No. & Competence & $\begin{array}{c}\text { Relevance Rating } \\
(\%)\end{array}$ \\
\hline $\mathbf{1}$ & PL1 & $89.32 \%$ & 12 & PL12 & $89.97 \%$ \\
$\mathbf{2}$ & PL2 & $91.33 \%$ & 13 & PL13 & $92.77 \%$ \\
$\mathbf{3}$ & PL3 & $90.88 \%$ & 14 & PL14 & $92.14 \%$ \\
$\mathbf{4}$ & PL4 & $89.53 \%$ & 15 & PL15 & $90.94 \%$ \\
$\mathbf{5}$ & PL5 & $89.85 \%$ & 16 & PL16 & $91.42 \%$ \\
$\mathbf{6}$ & PL6 & $90.89 \%$ & 17 & PL17 & $90.79 \%$ \\
$\mathbf{7}$ & PL7 & $91.42 \%$ & 18 & PL18 & $88.98 \%$ \\
$\mathbf{8}$ & PL8 & $92.31 \%$ & 19 & PL19 & $91.24 \%$ \\
$\mathbf{9}$ & PL9 & $89.89 \%$ & 20 & PL20 & $89.73 \%$ \\
$\mathbf{1 0}$ & PL10 & $88.96 \%$ & 21 & PL21 & $90.42 \%$ \\
$\mathbf{1 1}$ & PL11 & $89.56 \%$ & & & \\
\hline
\end{tabular}

Based on explanation above this level of relevance, then it can be concluded that the degree of relevance in light of the vehicle's electrical maintenance of competencies between the vehicle's engineering curriculum documents Lightweight Vocational High School with competency work needed by the corporate world or the world industry is $21 / 21 \times 100 \%=100 \%$, fall into the category of high relevance level.

Based on the results of the research in general, the percentage of the overall level of relevance between the documented curriculum on Light Vehicles with engineering competence that needed by the business world or the world of industry, there were 70 grains of competencies consists of 21 grains competency engine maintenance light vehicles, 28 grains competence maintenance chassis and a lightweight vehicle power mover, and 21 rounds of competence maintenance electrical light vehicles. There are 4 categories of entry less relevant competence with a percentage of $5,7 \%, 10$ 
incoming competencies categories quite relevant to the percentage of $14 \%, 51$ competencies entry categories relevant to the percentage of $71,8 \%$, and 6 entrance competencies the category is very relevant to the percentage of $8,5 \%$.

Based on the research 's result above, it provide a description of that vehicle engineering curriculum documents Lightweight Vocational High School hadn't been able to meet all the work competency that needed by the business world or the world automotive industry field. It is important to note in the course of curriculum development that all the competencies taught at Vocational High School working competence need the business world or the world of industry. So graduates have the Vocational High School high competitiveness to enter the world of work.

\section{References}

[1] Masriam Bukit. Strategi dan Inovasi Pendidikan Kejuruan: Dari Kompentensi Ke Kompetensi, Bandung: Alfabeta. (2014)

[2] Maclean, R. \& Wilson, D. International Handbook Of Education For The Changing World Of Work. Bonn: UNEVOC International Centre for TVET. (2009)

[3] Simon, F.H. Psioner's Work and Vocational Training. New York: Routledge. (1999)

[4] Billent, S. Vocational Education: Purposes, Traditions and Prospects. London:Springer Science Business Media B.V. (2011)

[5] Burke, J. Competency Based Eduction And Training. London: Taylor \& Francis e-Library. (2005)

[6] Canado, M.L.P., (Ed). Competency-Based Language Teaching In Higher Education.London: Springer Science Business Media. (2013)

[7] McKernan, J. Curriculum And Imagination. New York : Routledge Taylor \& Francis Group. (2008)

[8] Sugiyono Metode Penelitian Pendidikan: Pendekatan Kuantitatif, Kualitatif, dan R\&D. Bandung: Alfabeta. (2013) 